\title{
Molecular Identification and Sexual Differentiation of Freshwater Mud Eel, Monopterus cuchia
}

\author{
Md. Faruque Miah ${ }^{1, *}$, Fahmida Haque ${ }^{1}$, Mohammad Robin Mia ${ }^{1}$, Enaya Jannat ${ }^{1}$, Hafij Ali ${ }^{1}$, \\ M. M. A. Quddus ${ }^{2}$, Kawser Ahmed ${ }^{3}$ \\ ${ }^{1}$ Department of Genetic Engineering and Biotechnology, Shahjalal University of Science and Technology, Sylhet, Bangladesh \\ ${ }^{2}$ Department of Zoology, University of Dhaka, Bangladesh \\ ${ }^{3}$ Department of Oceanography, University of Dhaka, Bangladesh \\ *Corresponding Author: faruque-btc@sust.edu
}

Copyright (C) 2013 Horizon Research Publishing All rights reserved.

\begin{abstract}
This study was carried out for molecular identification and sexual differentiation of freshwater mud eel, Monopterus cuchia which is most important for induced breeding. Traditional classification of freshwater eels has always been obscurerd and unreliable due to their morphological ambiguity. A rapid and cost effective molecular markers, mitochondrial $16 \mathrm{~S}$ rRNA and glutamine synthetase gene was used to establish molecular standards for identification of this fish. Similar bands were seen in all the individuals at the level of $250 \mathrm{bp}$ length by using $16 \mathrm{~s}$ mitochondrial DNA of 24 individuals and 544bp length for partial sequence of glutamine synthetage gene in 11 individuals. A successful protocol was developed to identify male and female M. cuchia through morphological, anatomical and histological analysis.
\end{abstract}

Keywords 16s Mt NA, Gsase Gene, Molecular Identification, Sexual Differentiation, Monopterus Cuchia

\section{Introduction}

Monopterus cuchia [1] is commonly found in open water, mud holes, haors, canals, beels, paddy fields and floodplains with natural care of different districts of Bangladesh [2]. With ecological importance and high nutritional components this fish can play a unique role for the development of socio-economic status of fishermen as well as with short of culture practice [3]. Due to its tremendous demand in abroad this fish can play a great role in the national economy of the country by earning foreign currency as well. M. cuchia is a low-cost enterprise to the farmers for the simple culturing advantage in a small tank, aquarium and other vessels giving more profit than some other small size fish culture activities $[4,5]$. However, recently, due to extreme amount of export causes this fish reduced from nature [6,7] faster than any other time in past. Due to its high economic, ecological, nutritional and medicinal values, the research on this fish is most appropriate to enhance the stock in nature in terms of its conservation, breeding, culture and production. Proper species identification is the most important for developmental plan while traditional morphometric species identification leads to inaccuracy due to external similarities with other similar species [8]. For instance, it is very difficult to distinguish different species of eel based on morphological features [9]. Since the external morphology of Japanese eel, European eel, and American eel is quite similar to each other as well as different Monopterus species, it is necessary to apply a more sensitive and rapid method for species identification. Furthermore, the identification of early life stages (egg and larvae) is even more complicated than adult identification [8]. Therefore, appropriate identification of this fish is essential for the proper development of this fish.

Although there are some other commercially important freshwater fish like M. albus, European eel, Japanese eel etc. has been used for artificial or induced breeding throughout the world, no work on induced breeding has been recorded in M. cuchia. Due to high economic importance this fish is necessary to observe and produce high quality seeds through induced breeding/artificial breeding. Therefore, in this experiment PCR based molecular technique was used for identification of freshwater mud eel using two sets of primers. Also, sexual differentiation of freshwater mud eel, M. cuchia was also studied.

\section{Materials and Methods}

\subsection{Collection of Fish}

Fish samples were collected by fisherman from "Tanguar Haour", Sunamganj and then identified through morphological characteristics $[2,10]$. Collected fish samples were brought to the laboratory of Genetic Engineering and 
Biotechnology at Shahjalal University of Science and Technology, Sylhet, Bangladesh and were kept into glass aquariums until tissue isolation for molecular and histological analysis as well as for studying external and internal anatomy.

\subsection{Molecular Identification}

\subsection{DNA extraction}

Each fish was dissected and different tissue samples (i.e. liver, kidney etc.) were isolated and washed with distilled water and $70 \%$ alcohol. Then, the tissues were preserved separately in $100 \%$ alcohol at $-20^{\circ} \mathrm{C}$. DNA extraction was carried out by using a commercially available kit, Bioserve, CAT.NO.2025. A total of 24 fish samples were used for DNA extraction and extracted DNA samples were stored at $-20^{\circ} \mathrm{c}$. The quality of DNA was checked by electrophoresis on $0.8 \%$ agarose gel comparing with $30 \mathrm{bp}$ long lamda DNA.

The gel was run at $70 \mathrm{~V}$ for 40 minutes dying with ethedium bromide solution. Finally, photographs were taken by digital camera using gel documentation system.

\subsubsection{PCR amplification}

Vertebrate universal primer, accession no. 16SrRNA L2513 (5' GCCTGTTTACCAAAAACATCAC 3') and accession no. 16SrRNAH2714 (5' CTCCATAGGGTCT TCTCGTCTT 3') [11] as well as gene specific primer of glutamine synthetase, accession no. GSase 152041 (5' GAGGGCTCCAACAGCGATATGTA 3') and accession no. GSase 152042 (5' CTGAAGTTTGTATGGCAGCC AGC 3') [12] were used to identify the species. PCR reaction was done for both the primers with $25 \mu 1$ of master mix for each sample. In this experiment PCR reaction of $16 \mathrm{~s}$ mitochondrial DNA was conducted by 40 cycles with preheated at $94^{\circ} \mathrm{C}$ for 3 minutes followed by denaturation at $94^{\circ} \mathrm{C}$ for 1 minute, annealing at $58^{\circ} \mathrm{c}$ for 1 minute and 2 minutes for extension at $72^{\circ} \mathrm{C}$. A final step of $7 \mathrm{~min}$ for $72^{\circ} \mathrm{C}$ was added to allow complete extension of the amplified fragments. PCR amplification of glutamine synthetage gene was maintained like $16 \mathrm{~s}$ mtDNA, where denaturation at $94^{\circ} \mathrm{C}$ for $1 \mathrm{~min}$. and annealing temperature at $640 \mathrm{C}$ for $1 \mathrm{~min}$. and run with 35 cycles. Amplified products were stored at $-20^{\circ} \mathrm{C}$. The amplified DNA fragments were separated on $1.2 \%$ agarose gel for 40 minutes at $70 \mathrm{~V}$ comparing with 1000 bp ladder. Next, the photographs were taken by a digital camera using gel documentation system.

\subsection{Sexual Differentiation}

Male and female were identified by morphological, internal anatomy and histological analysis. Note that, Morphological study was observed by naked eye with important characteristics [13,14]. Specifically, some measuring parameters were analyzed using measuring scale and lifting balance. Different internal organs especially gonads, liver, kidney and intestine were observed through dissection process. Also, gonad shape, size, length etc. and sperm duct or oviduct was analyzed. Moreover, the number of mature eggs in the oviduct was also counted. We, at the same time, studied the histological analysis of gonads using microtomy.

\section{Results}

\subsection{Molecular Identification}

PCR products of two agarose gels with 24 samples were analyzed using 16s mitochondrial DNA for identification of the freshwater mud eel, Monopterus cuchia. Fifteen individuals were first gel with nice bands except the individual 1, 12, and 13 (Figure 1) and each DNA sample shows clear bands at the position of $250 \mathrm{bp}$ length based on the $1000 \mathrm{bp}$ length ladder whereas the ranges of ladder was started at $250 \mathrm{bp}$ length.

$$
\begin{array}{llllllllllllllll}
\mathrm{L} & 1 & 2 & 3 & 4 & 5 & 6 & 7 & 8 & 9 & 10 & 11 & 12 & 13 & 14 & 15
\end{array}
$$

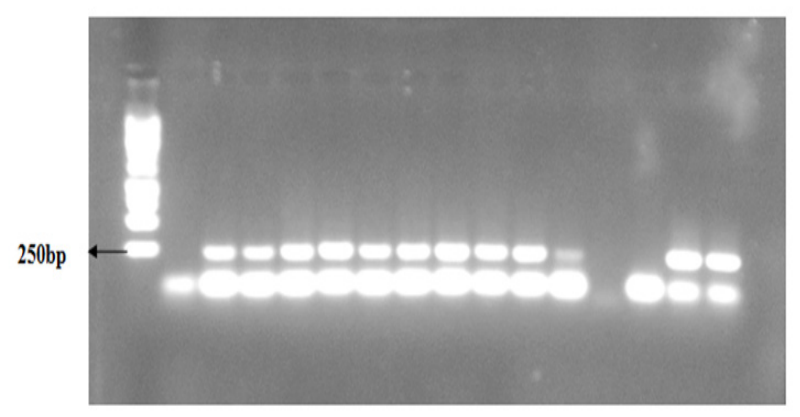

Figure 1. CR products of 15 individuals using16s mitochondrial DNA

In the second gel with 9 individuals clear bands were found except individual 23 and 24 (Figure 2) and all samples show fine bands at the position of $250 \mathrm{bp}$ length. Unfortunately, primer-dimer mixture was seen in both gels.

$$
\begin{array}{llllllllll}
\text { L } & 16 & 17 & 18 & 19 & 20 & 21 & 22 & 23 & 24
\end{array}
$$

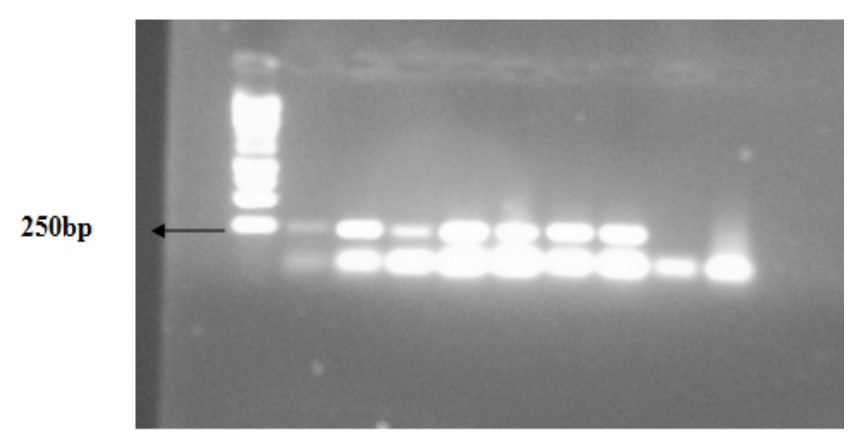

Figure 2. CR products of 9 individuals using16s mitochondrial DNA

$544 \mathrm{bp}$ long partial sequence of glutamine synthetase gene of 11 individuals was analyzed for identification of freshwater mud eel while found similar bands at 544bp lengths compared with $1000 \mathrm{bp}$ ladder as marker (Figure 3). 
In this case the ranges of the ladder were also started from 250 bp length.

$\begin{array}{llllllllllll}\mathrm{L} & 1 & 2 & 3 & 4 & 5 & 6 & 7 & 8 & 9 & 10 & 11\end{array}$

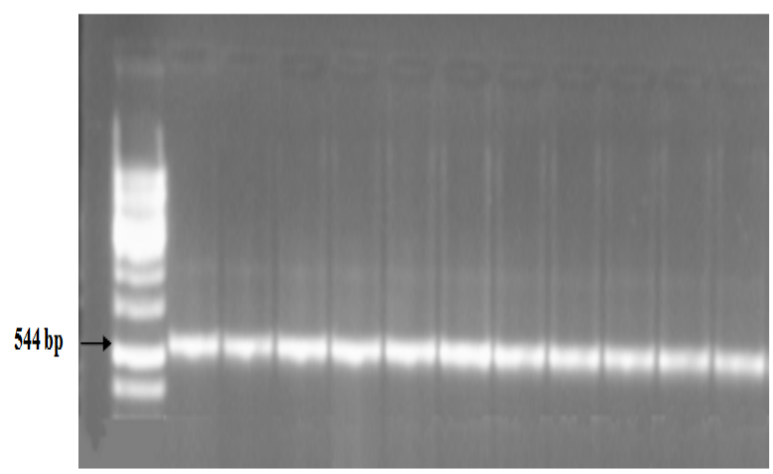

Figure 3. CR amplification result of glutamine synthetase gene in 11 fish

\subsection{Sexual differentiation}

Taxonomically the experimental fish was identified by the study of some important morphometric characteristics. Identification of male or female fish is so difficult but some external characteristics are helpful to observe sexual differentiation during breeding season. The body of the experimental fish is long and slender, and seems scale less. Actually, it has smooth, tiny scales that are embedded in the skin. Head is long and tapers to a small mouth consisting two small eyes on the head. Mature age male fish length approximately $60-65 \mathrm{~cm}$ and weight was near about 500-600g. But mature female was larger than male fish. The abdomen of female fish is swollen and brownish in colour with rough abdominal skin. Anus and genital pore was observed as tubular in male round shape in female (Figure 4).

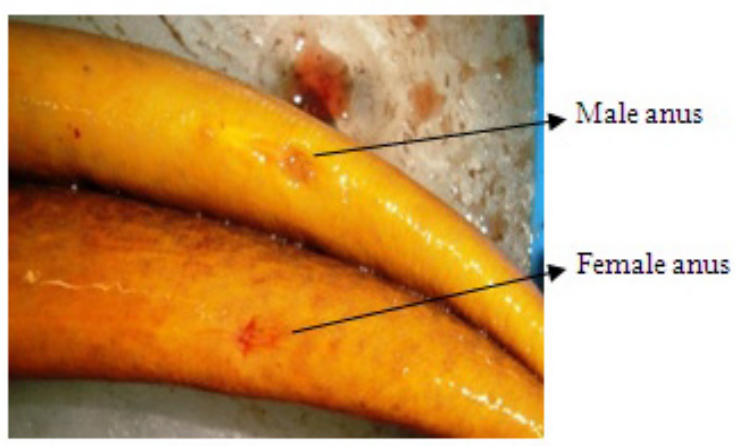

Figure 4. Male and female Monopterus cuchia

Internally, single gonad of both sexes comprised of a white, smooth, ribbon-like structure extending longitudinally below the gut and above the kidney for the entire length of the abdominal cavity. In male two equal, very thin, narrow and long sperm ducts were observed which is extended from anus to liver (Figure 5). However, single tubular oviduct was found in female with eggs from urinogenital opening to anterior part of the gall bladder (Figure 6). The ovary length was found in $11.2 \mathrm{~cm}$ and brownish in colour (Figure 6) while the sperm duct was almost $15 \mathrm{~cm}$ long and white in colour
(Figure 5). In an average 600 round eggs were found in the experimental females and the egg size was ranged between $0.1 \mathrm{~mm}$ to $0.7 \mathrm{~mm}$ in diameter.

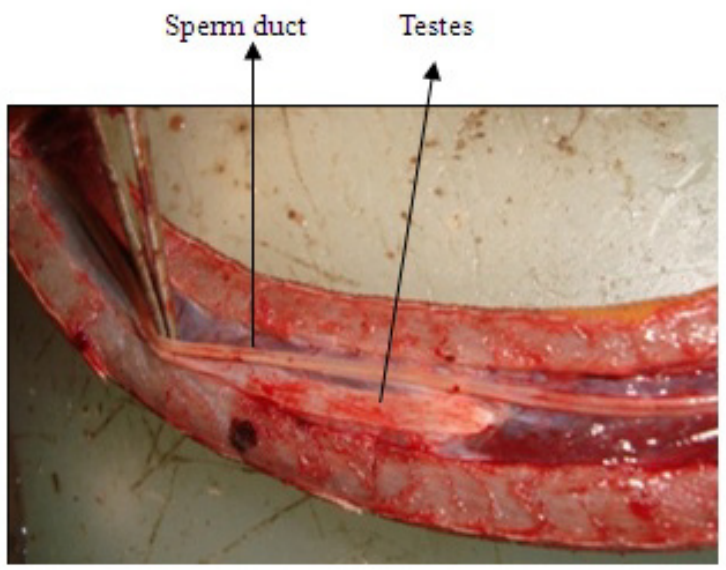

Figure 5. Male genital organ of Monopterus cuchia

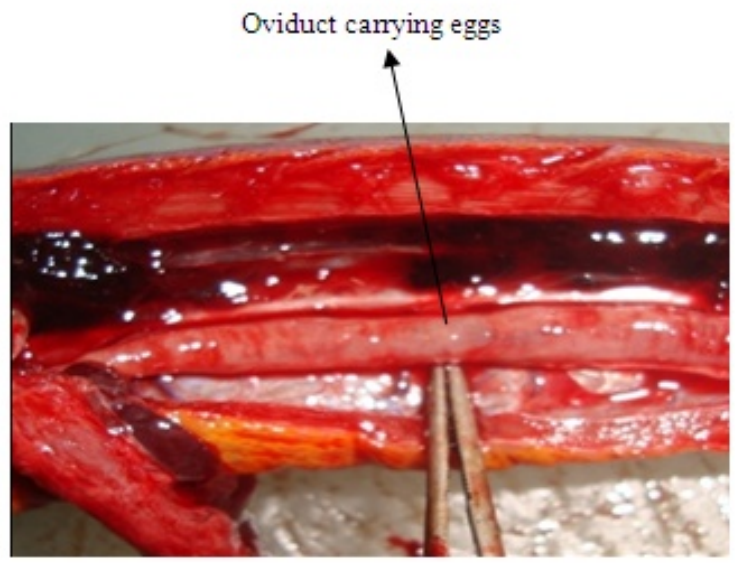

Figure 6. Ovary of female Monopterus cuchia

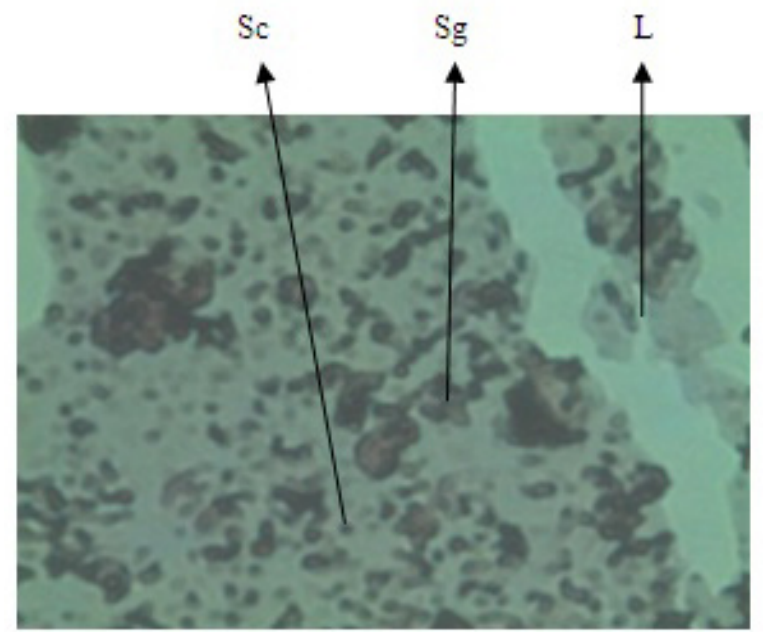

Figure 7. Histological sections of testis ( $\mathrm{Sg}$, spermatogonia; $\mathrm{Sc}$, spermatocytes; L, lumen)

Histologically, the testis was dominated by the presence of small spermatogonia and is recognizable by the more compact within a tubular arrangement with more cells. The 
testis has well-defined tubules with clear lumina which have spermatocytes on their inner margin. Spermatocytes are recognizable by their smaller nuclear size and darkly staining chromatin material (Figure 7).

Ovary was dominated by the presence of vacuolated oocytes and an increase in oocyte size is associated with cytoplasm that is less basophilic. Immature cells with small vacuoles were observed at the periphery of the oocyte and the vacuoles gradually move towards the nucleus of mature cells (Figure 8).

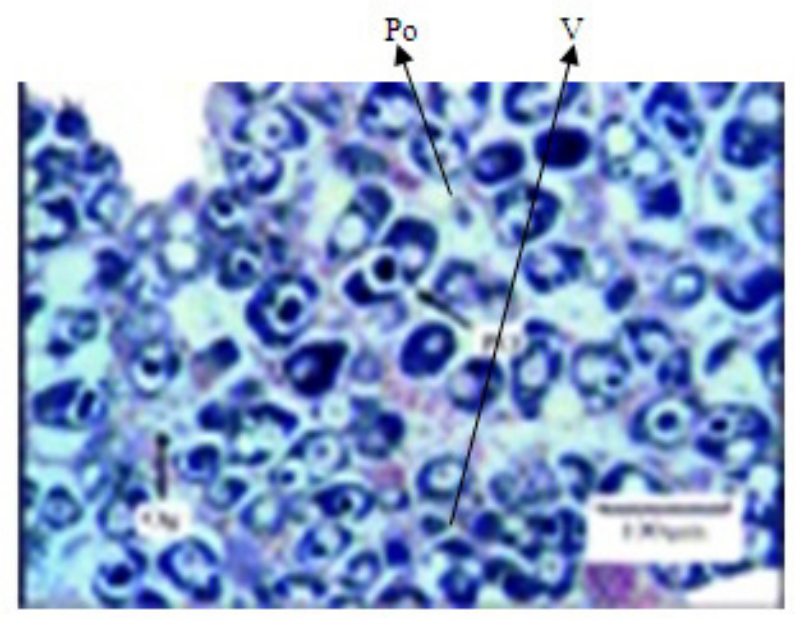

Figure 8. Histological sections of representative ovary $(\mathrm{Og}$, oogonia; PO, primary oocytes; V, vacuoles).

\section{Discussions}

Efficient identification of this eel species is critical for aquaculture management as well as for eel conservation particularly in Bangladesh [15]. Thus, identification of $M$. cuchia needs to be supported by molecular characterization instead of conventional methods [16]. Inexpensive, simple, rapid PCR based techniques mitochondrial 16s ribosomal RNA could be used to identify $M$. cuchia which is already designed a universal primer for species identification [11].

16s mitochondrial DNA is a universal primer which can successfully amplify the expected PCR products from various kinds of vertebrates including mammals, birds, reptiles, amphibians, fish, etc, and the sequenced segments contained sufficient nucleotide difference to identify each animal species [11]. Different molecular techniques already established to identify freshwater eels such as RFLP analyses of PCR amplified DNA, fragments and allele-specific PCR from mitochondrial DNA [17]. 12S rRNA, 16S rRNA, D-loop and cytochrome $b$ genes are generally used for fish identification, and in this research successfully amplify $16 \mathrm{~S}$ rRNA gene and find all this individuals at the same length of DNA with $250 \mathrm{bp}$ long.

544bp long partial sequence of glutamine synthestase gene was expressed in M. cuchia [12] which was used in this study for the identification of this fish. Among two primers glutamine synthetase contains GC content higher than the 16s mitochondrial DNA. However, in this experiment the same length 544 bp long DNA band was found in all individuals. In this research $16 \mathrm{~S}$ rRNA and glutamine synthetage gene was used for the first time and a successful technique was developed for species identification of this fish.

Sexual differentiation of different commercial fish even though some other eels such as Anguilla Reinhardtii [18], A. anguilla [19] and Monopterous albus [20] were observed traditionally but no record was available for this $M$. cuchia. In this experiment male and female $M$. cuchia was separated by external, internal and histological characteristics. As $M$. albus is recorded hermaphrodite where bisexual characteristic was found in M. cuchia through the present study. Sex-specific growth trajectories in freshwater eels are well documented by different above researches. The prevailing view is that females grow faster than males [21-25] while similar results were found also in this experiment in $M$. cuchia.

\section{Conclusion}

Proper species identification and sexual differentiation of a species is the most important for induced breading. Due to morphological ambiguity of different freshwater eels, species identification has always been difficult and unreliable. This study made a rapid and cost effective protocol of $M$. cuchia through DNA technique. On the other hand, sexual differentiation of this species was established through morphometric and histological analysis for, suitable differentiation between male and female fish.

\section{Acknowledgements}

This research was done by the research project entitled "Development of Artificial Breeding (Induced Breeding and Selective Breeding) and Production Techniques of Freshwater Mud Eel, Monopterus cuchia in Bangladesh" which is done under the financial support of the Government of the People's Republic of Bangladesh through Ministry of Science and Technology. We are cordially indebted to Ministry of Science and Technology of Bangladesh for giving this financial support.

\section{REFERENCES}

[1] F. Hamilton. An account of the fishes found in the river Ganges and its branches. Edinburgh \& London. I-VII + 1-405, Pls. 1-39, 1822.

[2] A. A. K. Rahman. "Freshwater Fishes of Bangladesh," Zoological Scienceof BangladeshUniversity of Dhaka, 364p, 1989. 
[3] M. M. A. Quddus, A. K.Banerjee, F. Parveen, R. Ara, \&M. P. Costa. Development of social fishery technology using small indigenous fishers of Bangladesh. Dhaka University J. of Biol. Sci., 9(2): 131-138,2000.

[4] D. Y. Lu, P. Song, Y. G. Chen,M. X. Peng, J. F. Gui. Expression of gene vasa during sex reversal of Monopterus albus. Acta Zoological Sinica, 51(3): 469-475, 2005.

[5] IIRR, IDRC, FAO, NACA and ICLARM. Utilizing Different Aquatic Resources for Livelihoods in Asia: a resource book. International Institute of Rural Reconstruction, International Development Research Centre, Food and Agriculture Organization of the United Nations, Network of Aquaculture Centers in Asia-Pacific and International Center for Living Aquatic Resources Management, 2001.

[6] A. G. Ponniah. Bull Cent. Inland Fish. Res. Inst. Barrackpore No. 101-178, 2000.

[7] M. S. Hossian, \& M. A. Mazid. A manual on development of floodplain fisheries. Fisheries Research Institute, Mymensingh, 2,1995.

[8] R. E. Strauss \& C. E. Bond. Taxonomic methods: morphology In: Methods for Fish Biology (P. Moyle and C. Schreck, eds.). American Fisheries Society, Special Publication, 109-140,1990.

[9] C. Callejas \&M. D. Ochando. Molecular identification (RAPD) of the eight species of the genus Barbus (Cyprinidae) in the Iberian Peninsula. J. Fish Biol. 59: 1589-1599, 2001.

[10] P. K. Talwar \&A. G. Jhingran,Inland Fishes of India and adjacent countries. Oxford and IBH publishing Co. Pvt. Ltd. 2: 776-777, 1991.

[11] T. Kitano, K. Umetsu, W. Tian\&M. Osawa. Two universal primer sets for species identification among vertebrates. Int J Legal Med., 121(5):423-427, 2007.

[12] N. Saha, B. Banerjee, H. Hangzo, \&G. Bhuyan. Expression of glutamine synthetase (GS01) in freshwater mud eel, Monopterus cuchia. INSDC. Zoology, North-Eastern Hill University, India.2010.

[13] A. L. Bhiyan. The Fishes of Dhaka. Asiatic Society of Pakistan, Publ No. 13: 148 pp, 1964.

[14] K. C. Jayaram, Methods of preservation of fishes, p. 5. In: Director, ZSI (ed.). The Fresh Water Fishes of India, Pakistan, Bangladesh, Burma and Srilanka - A Handbook. Calcutta Laser Graphics (P) Ltd., Calcutta, iii: 475-13, 1981.
[15] A. Dudu, S. E. Georgescu,\& M. Costache. PCR-RFLP method to identify fish species of Importance Archiva Zootechnica, 13(1):53-59, 2010.

[16] J. P. Huang,Y. S. Han, W. N. Tzeng. Species identification of Anguillid eels by polemerase chain reaction/restriction fragment length polymorphism analysis of the gonadotrophin II- $\beta$ subunit gene. Acta Zoologica Taiwanica, 12(2): 41-49, 2001.

[17] S. Y Lin, P. Y. Poh, \& C. S. Tzeng. Molecular Techniques to Identify Freshwater Eels: RFLP Analyses PCR-amplified DNA Fragments and Allele-specific PCR from Mitochondrial DNA Zoological Studies, 41(4): 421-430, 2002.

[18] J. P. Berumer. Feeding and movement of Anguilla australis and Anguilla reinhardtii in Macleods morass, Victoria, Australia. J. Fish Biol.14: 573-592, 1979.

[19] V. R. P. Sinha, J. W. Jones. On the food of the freshwater eels and their feeding relationship with the salmonids. Journal of Zoology, London 153:119-137, 1967.

[20] Y. C. Huang,S. S. Jeng, H. M. Chen, \& D. F. Hwang. Identification of nine species of moray eel by SDS-PAGE the Raffles Bulletin of Zoology, 19: 123-129, 2008.

[21] L. A. Vøllestad \& B. Jonsson. Life-history characteristics of the European eel Anguilla anguilla in the Imsa River, Norway. Transactions of the American Fisheries Society, 115 (6): 864-871, 1986.

[22] W. R. Poole \& J. D. Reynolds. Growth rate and age at migration of Anguilla anguilla. J. Fish Biol. 48(4):633-642, 1996.

[23] K. Holmgren, H. Wickstrom, \& P. Clevestam. Sex-related growth of European eel, Anguilla anguilla, with focus on median silver eel age. Canadian Journal of Fisheries \&Aquatic Sciences 54: 2775-2781, 1997.

[24] A. S. Oliver. Size and density dependent mating tactics in the simultaneously hermaphroditic seabass Serranus subligarius (Cope, 1870). Behaviour 134: 563-594, 1997.

[25] K. Oliveira \& J. D. McCleave. Sexually different growth histories of the American eel in four rivers in Maine. Trans. Am. Fish. Soc. 131:203-211, 2002. 